\title{
Overcoming dormancy in New Mexico mountain mahogany seed collections
}

\author{
LEE S. ROSNER, JOHN T. HARRINGTON, DAVID R. DREESEN, AND LEIGH MURRAY
}

Authors are Science Specialist, Department of Agronomy and Horticulture, New Mexico State University, Las Cruces, N.M. 88003; Associate Professor, New Mexico State University Mora Research Station, Mora, N.M. 87732; Agronomist, USDA Natural Resource Conservation Service, Los Lunas, N.M., 87031; and Professor, Department of Experimental Statistics, New Mexico State University, Las Cruces, N.M. 88003

\begin{abstract}
Mountain mahogany (Cercocarpus montanus Raf) is a useful reclamation species because it can occupy and improve poor soils. Literature regarding seed propagation of this species is varied and often contradictory, recommending stratification durations of 14 to 90 days, and sulfuric acid scarification durations of none to 60 minutes. To assess variability in propagation requirements among seed sources, 8 New Mexico seed sources were tested with factorial combinations of scarification and stratification treatments. Sources were selected to encompass both a range of latitudes throughout New Mexico and a range of elevations at Questa, N. M. Seeds were scarified 5 or 10 minutes in concentrated sulfuric acid, tumbled 5 or 10 days in course grit, or unscarified (control). Seeds underwent subsequent stratification for 0 (control), 30, or 60 days. Averaged across scarification treatments, the 2 southernmost sources lacked a stratification requirement, while northern seed sources achieved their highest germination following the longest stratification duration (60 days). Improvement in germination due to stratification was greatest for the 2 highest elevation Questa sources. Scarification treatments were less effective in improving germination than stratification treatments, and produced more variable results. A 5-minute soak in sulfuric acid was the most effective scarification treatment, but for 2 sources, this treatment reduced germination. Variability in the stratification requirement appears to be an adaptation to macroclimatic differences among seed sources, whereas differential response to scarification may be a response to microclimatic differences.
\end{abstract}

Key Words: acid scarification, stratification, ecotypic variability, Cercocarpus montanus

Mountain mahogany (Cercocarpus montanus Raf) occupies sites that are dry, unstable, erosive, and of low fertility (Brotherson 1992), and is actinorhizal, forming a nitrogen-fixing symbiosis with Frankia bacteria (Paschke 1997). These characteristics make it an excellent shrub species for reclamation in the western United States. Poor germinability has proven to be an obstacle to production of seedlings for revegetation, and propagation literature is inconsistent and often contradictory.

This research was funded, in part, through grants from McIntire Stennis, Molycorp Inc. of Questa, N.M., and the New Mexico Agriculture Experiment Station.

Manuscript accepted 12 Jun. 02

\section{Resumen}

El "Mountain mahogany" (Cercocarpus montanus Rat) es una especie útil para la restauración de pastizales porque puede ocupar y mejorar suelos pobres. La literatura respecto a la propagación de semilla de esta especie es variada y a menudo es contradictoria, recomendando periodos de estratificación de 14 a 90 días y tiempos de escarificación con ácido sulfúrico de nada a 60 minutos. Para evaluar la variabilidad en requerimientos de propagación entre fuentes de semilla se evaluaron 8 fuentes de semilla provenientes de New Mexico en combinación factorial de tratamientos de escarificación y estratificación. Las fuentes de semilla fueron seleccionadas para abarcar un rango de altitudes a través de New Mexico y un rango de elevaciones en Questa, $\mathbf{N}$. $M$. Las semillas fueron escarificadas por 5 o 10 minutos en ácido sulfúrico concentrado, agitadas 5 o 10 días en una cama de arena o sin escarificar (control). Las semillas recibieron una estratificación subsecuente de 0 (control), 30 o 60 días. Promediando a través de los tratamientos de escarificación, se detectó que las dos fuentes de semilla de mas al sur no requirieron de estratificación, mientras que las fuentes de semilla del norte alcanzaron los más altos porcentajes de germinación con el tratamiento de estratificación mas largo (60 días). La mejoría en la germinación debida a la estratificación fue mayor para las 2 fuentes de semilla de mayor altitud en Questa. Los tratamientos de escarificación fueron menos efectivos en mejorar la germinación que los tratamientos de estratificación y produjeron resultados más variables. Un remojo de 5 minutos en ácido sulfúrico fue el tratamiento de escarificación más efectivo, pero para en dos fuentes de semilla este tratamiento redujo la germinación. La variabilidad en los requerimientos de estratificación parece ser una adaptación las diferencias macroclimáticas entre las fuentes de semilla, mientras que la respuesta diferencial a la escarificación puede ser una respuesta a diferencias microclimáticas.

Published literature recommends stratification at 0 to $5^{\circ} \mathrm{C}$, but recommended treatment durations vary from 14 to 90 days (Hervey 1955, Heit 1970, Smith 1971, Deitschman et al. 1974, Kitchen and Meyer 1990). Kitchen and Meyer (1990), studying Utah and Colorado seed sources, found the stratification requirement to vary from 42 to 84 days depending on source. Although the seed coat of mountain mahogany is permeable to water (Heit 1970), scarification treatments have been effective in promoting germination. Hervey (1955) reported that a 60-minute soak in acid improved germination. Dreesen (unpublished data) found incubation in acid for as short as 5 minutes to result in complete 
Table 1. Sources of mountain mahogany seed collected in September and October 1997 and used in germination studies.

\begin{tabular}{lllc}
\hline \hline Source & Latitude & \multicolumn{1}{c}{ Location } & Elevation \\
\hline Capulin & $36^{\circ} 42^{\prime} \mathrm{N}$ & Molycorp Mind-Questa, N.M. & $2,987 \mathrm{~m}$ \\
Blind Gulch & $36^{\circ} 42^{\prime} \mathrm{N}$ & Molycorp Mind-Questa, N.M. & $2,896 \mathrm{~m}$ \\
Mahogany Hill & $36^{\circ} 42^{\prime} \mathrm{N}$ & Molycorp Mind-Questa, N.M. & $2,774 \mathrm{~m}$ \\
Headframe Hill & $36^{\circ} 42^{\prime} \mathrm{N}$ & Molycorp Mind-Questa, N.M. & $2,560 \mathrm{~m}$ \\
Boxcar & $36^{\circ} 42^{\prime} \mathrm{N}$ & Molycorp Mind-Questa, N.M. & $2,499 \mathrm{~m}$ \\
Rociada & $35^{\circ} 50^{\prime} \mathrm{N}$ & Rociada, N.M. & $2,377 \mathrm{~m}$ \\
Sandia & $35^{\circ} 10^{\prime} \mathrm{N}$ & Cibola National Forest, N.M. & $2,835 \mathrm{~m}$ \\
Sacramento & $32^{\circ} 58^{\prime} \mathrm{N}$ & Lincoln National Forest, N.M. & $2,621 \mathrm{~m}$ \\
\hline
\end{tabular}

seed destruction. Heit (1970) found that a 10-minute soak in acid increased germination speed but not percentage, while a 20 minute soak injured seeds.

Inconsistencies among propagation protocols for mountain mahogany may be related, in part, to extensive ecotypic variability (Young et al. 1978). This study was undertaken to assess variability in response to stratification and scarification treatments among 8 New Mexico collections of mountain mahogany selected across latitudinal and elevational gradients.

\section{Materials and Methods}

Seeds were collected from 8 New Mexico sources (Table 1). Sources were selected to encompass both a range of latitudes throughout New Mexico and a range of elevations at Molycorp Mine in Questa, N.M. Seeds were collected from a minimum of 5 plants at each source. Seeds were considered ripe when easily removed from the plant. Styles were separated from seeds in a rubbing box, and seeds were then separated from debris in a Dakota blower. Cleaned seeds were stored at $5^{\circ} \mathrm{C}$ for over 2 years until the start of the study. At this temperature, seeds retain viability for at least 6 years (Springfield 1973).

Limited seed availability restricted the number of sulfuric acid and dry-tumble scarification treatments imposed on 3 of 8 sources used in this study. As a result, the study consisted of 2 overlapping experiments generating 2 data sets. The first experiment tested a factorial combination of all 8 seed sources, 3 scarification treatments (unscarified control, 5-minute sulfuric acid soak, and 5-day dry-tumble treatment), and 3 stratification lengths $(0,30$, or 60 days). The second experiment evaluated a factorial combination of 5 seed sources, 5 scarification treatments (unscarified control, 5-minute sulfuric acid soak, 10-minute sulfuric acid soak, 5-day drytumble treatment, and 10-day dry tumble treatment) and 3 stratification lengths $(0$, 30 , or 60 days). Results for the second experiment are presented only in regards to the 2 additional scarification treatments. Each treatment combination was tested with four, 100-seed replications. Due to missing data, the Sacramento source was not included in statistical comparisons. However, some germination data are presented for reference.

Seeds undergoing acid scarification were soaked in concentrated sulfuric acid (Reagent ACS, 95.0 to $98.0 \%$, VWR), then thoroughly rinsed under running tap water. Seeds underwent dry-tumble scarification mixed with $10 \mathrm{~g}$ course grit (True Square Metal Products) in a 4-ounce round ointment tin (US Can), which was placed within the canister drum of a No. 140 Model B High Speed Tumbler (Trusquare Metal Products) turning at approximately $40 \mathrm{rpm}$. Tins were tightly packed in the canister drum, so that each can rotated 360 degrees for each 360-degree rotation of the drum.

Before undergoing stratification treatment (or germination testing for stratification-control seeds) all seeds were soaked for 1 minute in hydrogen peroxide (VWR $3 \%$ Stabilized) for surface sterilization and thoroughly rinsed under running tap water. This step was undertaken to minimize potential differences in seed contamination between acid-treated and non-acidtreated seeds, which could have biased the results. Hydrogen peroxide can affect germination. However, when used as a seed pretreatment, much longer soak durations and/or higher concentrations are typically used (Young and Evans 1981, Rosner 2000).

Seeds undergoing stratification were spread evenly over half of a $20 \times 20 \mathrm{~cm}$ piece of cotton cloth that had been saturated with distilled water. The cloth was folded to enclose the seeds, placed within $15 \times 16 \mathrm{~cm}$ self-sealing poly bags, and covered with $200 \mathrm{ml}$ peat moss, which had been saturated with distilled water and squeezed by hand to remove excess water. Poly bags were placed in a walk-in cooler maintained near $5^{\circ} \mathrm{C}$ for the duration of stratification treatment.

Seeds were tested for germination between two, $20.5 \mathrm{~cm}$ filter papers (VWR Grade 413 Qualitative) saturated with distilled water. Filter papers were sealed in 1gallon self-sealing poly bags, which were placed on greenhouse benches. Thermostat settings in the greenhouse were adjusted to maintain daytime highs near $30^{\circ} \mathrm{C}$ and nighttime lows near $15^{\circ} \mathrm{C}$. Although testing germination over a wide range of controlled temperature regimes is necessary to fully characterize dormancy, germination testing was conducted in this manner to characterize the expression of dormancy in a typical greenhouse setting. Optimal germination temperature for this species varies among seed sources (Piatt 1976, Smith 1971, Smith and Bass 1973,

Table 2. Categorical analysis of variance tables for effect of scarification, stratification, seed source, and interactions of these factors on mountain mahogany germination.

\begin{tabular}{|c|c|c|c|c|c|c|c|c|c|}
\hline 8-Source Experiment ${ }^{\prime}$ & Component & df & Chi-Square & $\begin{array}{l}\text { Observed } \\
\text { Significance }\end{array}$ & 5-Source Experiment & Component & $\mathrm{df}$ & Chi-Square & $\begin{array}{l}\text { Observed } \\
\text { Significance }\end{array}$ \\
\hline \multirow{3}{*}{$\begin{array}{l}\text {-Control, 5-minute acid soak, and 5-day } \\
\text { dry-tumble scarification treatments. }\end{array}$} & $\mathrm{Scar}^{2}$ & 2 & 13.3 & $<.001$ & \multirow[t]{2}{*}{-All scarification treatments (5). } & $\mathrm{Scar}^{2}$ & 4 & 90.9 & $<.0001$ \\
\hline & Strat & 2 & 393.0 & $<.0001$ & & Strat & 2 & 326.8 & $<.0001$ \\
\hline & Source & 6 & 3710.5 & $<.0001$ & \multirow{5}{*}{$\begin{array}{l}\text {-Blind Gulch, Mahogany Hill, } \\
\text { Headframe Hill, Boxcar, and } \\
\text { Sandia seed sources. }\end{array}$} & Source & 4 & 4197.9 & $<.0001$ \\
\hline \multirow{4}{*}{$\begin{array}{l}\text {-Capulin, Blind Gulch, Mahogany Hill, } \\
\text { Headframe Hill, Boxcar, Rociada, } \\
\text { and Sandia seed sources. }\end{array}$} & Scar by Strat & 4 & 105.3 & $<.0001$ & & Scar by Strat & 8 & 147.6 & $<.0001$ \\
\hline & Scar by Source & 12 & 276.9 & $<.0001$ & & Scar by Source & 16 & 384.6 & $<.0001$ \\
\hline & Strat by Source & 12 & 159.3 & $<.0001$ & & Strat by Source & 8 & 120.5 & $<.0001$ \\
\hline & Scar by Strat by Source & 24 & 121.3 & $<.0001$ & & Scar by Strat by Source & 32 & 209.2 & $<.0001$ \\
\hline
\end{tabular}

${ }^{1}$ Sacramento source was dropped from this analysis leaving 7 sources.

${ }^{2}$ Scar $=$ Scarification. Strat $=$ Stratification 
Table 3. Mean germination percentages and standard errors for data averaged across stratification and scarification (control, 5minute acid soak, 5-day dry-tumble) treatments for each mountain mahogany seed source.

\begin{tabular}{lcc}
\hline \hline Seed Source & $\begin{array}{c}\text { Mean } \\
\text { Germination }\end{array}$ & $\begin{array}{c}\text { Standard } \\
\text { Error }\end{array}$ \\
\hline Capulin & $(\%)$ & \\
Blind Gulch & 19.6 & 0.7 \\
Mahogany Hill & 21.6 & 0.7 \\
Headframe Hill & 44.6 & 0.8 \\
Boxcar & 82.1 & 0.6 \\
Rociada & 64.8 & 0.8 \\
Sandia & 61.9 & 0.8 \\
Sacramento & 53.8 & 0.8 \\
\hline
\end{tabular}

Kitchen et al. 1989). Greenhouse temperatures during the germination test ranged from $28.2^{\circ} \mathrm{C} * 0.5^{\circ} \mathrm{C}$ for mean daytime highs to $13.9^{\circ} \mathrm{C} * 0.3^{\circ} \mathrm{C}$ for mean nighttime lows. Paper moisture level was maintained by application of distilled water as needed. Seeds were checked for germination after $0,7,14,21$, and 28 days. Seeds were considered germinated when the radical had emerged through the seed coat

Categorical analysis of variance (SAS Proc CATMOD, SAS Institute 1989) was used to determine treatment differences in germination using a factorial treatment structure. Analysis was also run separately by seed source. (Traditionally, analysis of variance [ANOVA] has been used to analyze germination data. The ANOVA assumes continuous, normally distributed

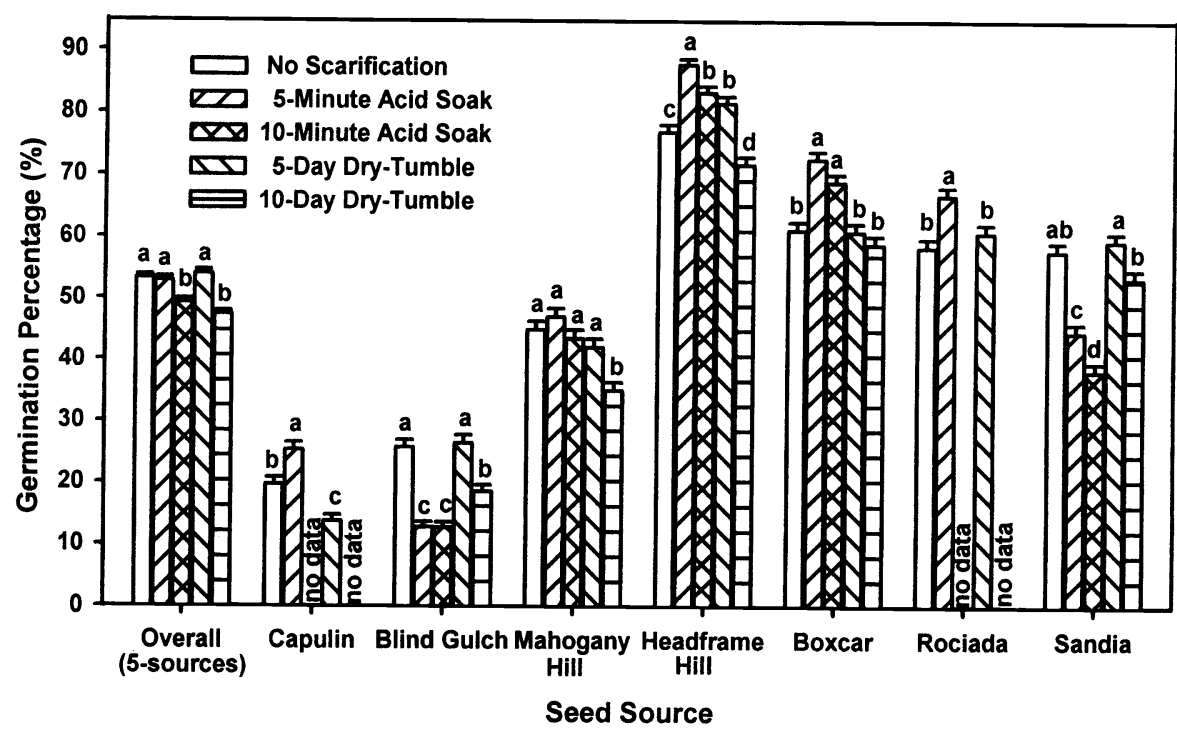

Fig. 2. Effect of scarification treatment and its interaction with seed source (averaged across stratification treatments) on mountain mahogany germination. Means labeled with the same letter are not significantly different at $\alpha=(0.05) / 3$-where 3 treatments are compared and $\alpha=(0.05) / 10$ - where 5 treatments are compared.

data with equal variances, but germination percentage data has unequal variances between treatments and is frequently skewed and, therefore, non-normal. Usually percentage data are arcsine transformed to achieve normality and then analyzed by ANOVA. Until, the advent of high-speed microcomputers, use of more appropriate categorical models for analysis of germination data was impractical.) Categorical analysis of variance is a generalization of the chi-square $\left(\mathrm{X}^{2}\right)$ test of

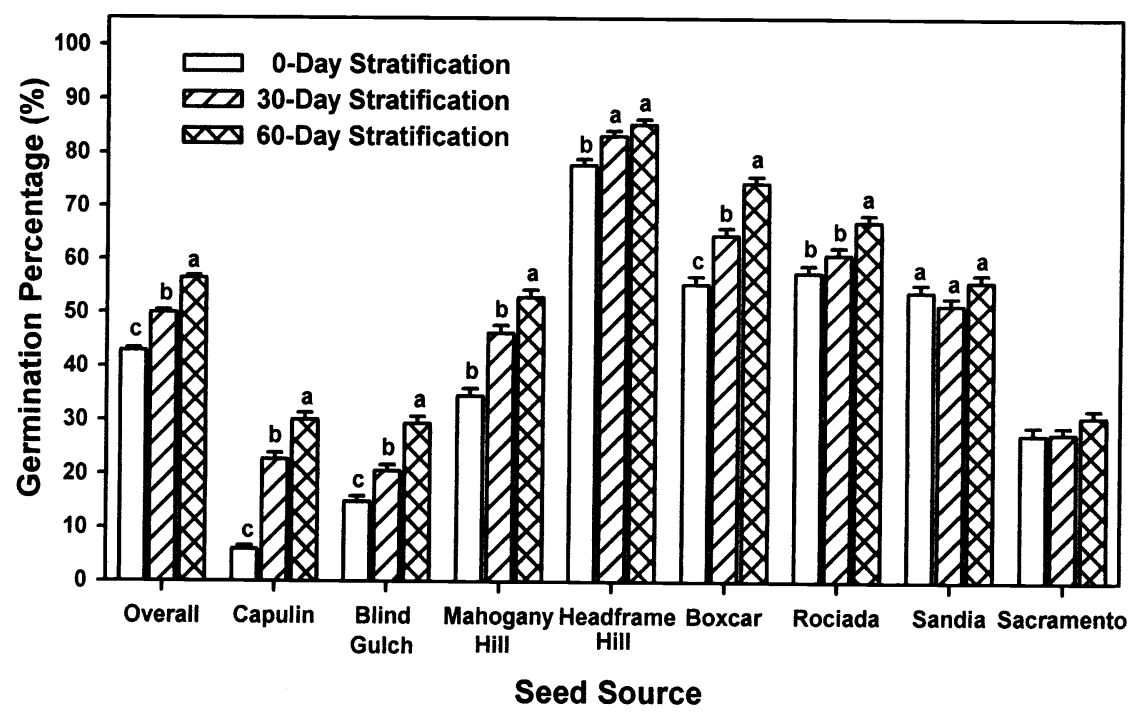

Fig. 1. Effect of stratification and its interaction with seed source (averaged across 3 scarification treatments) on mountain mahogany germination. Pairwise comparisons were omitted for the Sacramento source because they would be biased by a missing treatment combination. Germination means labeled with the same letter are not significantly different at $\alpha$ $=(\mathbf{0 . 0 5}) / 3$. homogeneity. The maximum-likelihood technique was used to calculate $\mathrm{X}^{2}$ test statistics. Observed significance levels less than 0.05 were considered significant. Percentages and standard errors were calculated for main effects and interaction combinations. Approximate pairwise Zstatistics were used to conduct pairwise comparisons of main treatment effects using a conservative alpha value of 0.05 divided by the number of comparisons.

\section{Results}

In both the 8-source and the 5-source experiments, scarification, stratification, seed source, and all interactions of factors affected germination (Table 2). Seed source had the greatest effect on germination. Germination percentages were highly variable among sources (Table 3) and were improved by stratification (for data averaged over seed sources and scarification treatments). A 60-day treatment was most effective (Fig. 1). Differences in response to stratification among seed sources (for data averaged across scarification treatments) conformed to a latitudinal gradient with germination improving in response to increasing stratification duration only for the 6 northern sources (all except Sandia and Sacramento) (Fig. 1). Percentage improvement due to stratification was greatest for the 2 Questa seed sources from highest elevation (Capulin and Blind Gulch) and least for the 3 southernmost sources (Rociada, Sandia, and 
Table 4. Improvement in mountain mahogany germination (percentage and SE) by seed source due to stratification treatment, for data averaged across 3 scarification treatments (control, 5-minute acid soak, 5-day dry-tumble).

\begin{tabular}{|c|c|c|c|c|c|c|c|c|}
\hline Stratification Duration & Capulin & $\begin{array}{l}\text { Blind } \\
\text { Gulch }\end{array}$ & $\begin{array}{c}\text { Mahogany } \\
\text { Hill }\end{array}$ & $\begin{array}{c}\text { Headframe } \\
\text { Hill }\end{array}$ & Boxcar & Rociada & Sandia & Sacramento \\
\hline & $(\%)$ & $(\%)$ & $(\%)$ & $(\%)$ & $(\%)$ & $(\%)$ & $(\%)$ & $(\%)$ \\
\hline 0 & $5.9(0.7)$ & $14.8(1.0)$ & $34.6(1.4)$ & $77.8(1.2)$ & $55.4(1.4)$ & $57.6(1.4)$ & $54.0(1.4)$ & $27.5(1.6)$ \\
\hline 30 days & $22.7(1.2)$ & $20.6(1.7)$ & $46.3(1.4)$ & $83.2(1.1)$ & $64.5(1.4)$ & $60.9(1.4)$ & $51.5(1.4)$ & $27.7(1.3)$ \\
\hline 60 days & $310.1(1.3)$ & $29.4(1.3)$ & $52.9(1.4)$ & $85.3(1.0)$ & $74.4(1.3)$ & $67.1(1.4)$ & $55.8(1.4)$ & $30.8(1.3)$ \\
\hline $\begin{array}{l}\text { Improvement following } \\
60 \text {-day stratification } \\
\text { relative to control }\end{array}$ & $410 \%$ & $99 \%$ & $53 \%$ & $10 \%$ & $34 \%$ & $16 \%$ & $3 \%^{1}$ & $12 \%^{2}$ \\
\hline
\end{tabular}

Germination percentages were not significantly different.

${ }^{2}$ Significance of improvement not tested because of missing treatment combinations.

Sacramento) and one northern source (Headframe Hill) (Table 4).

Scarification also affected germination percentage. Although no scarification treatment improved germination relative to control seeds for data averaged over seed sources, some treatments were effective for individual sources (Fig. 2). Acid scarification improved germination for 4 of 7 seed sources tested, but reduced germination for 2 seed sources. Dry-tumble scarification (averaged across stratification treatments) had little influence on germination, increasing germination for only 1 seed source. For the 5 sources evaluated, as scarification duration increased from either a 5-minute to a 10-minute acid soak or from a 5-day to a 10-day tumble scarification, total germination was either unaffected or reduced.

Response to scarification varied across stratification treatments (Fig. 3). Averaged across seed sources, the best acid soak (5 minutes) and dry-tumble (5-day) treatments improved germination appreciably

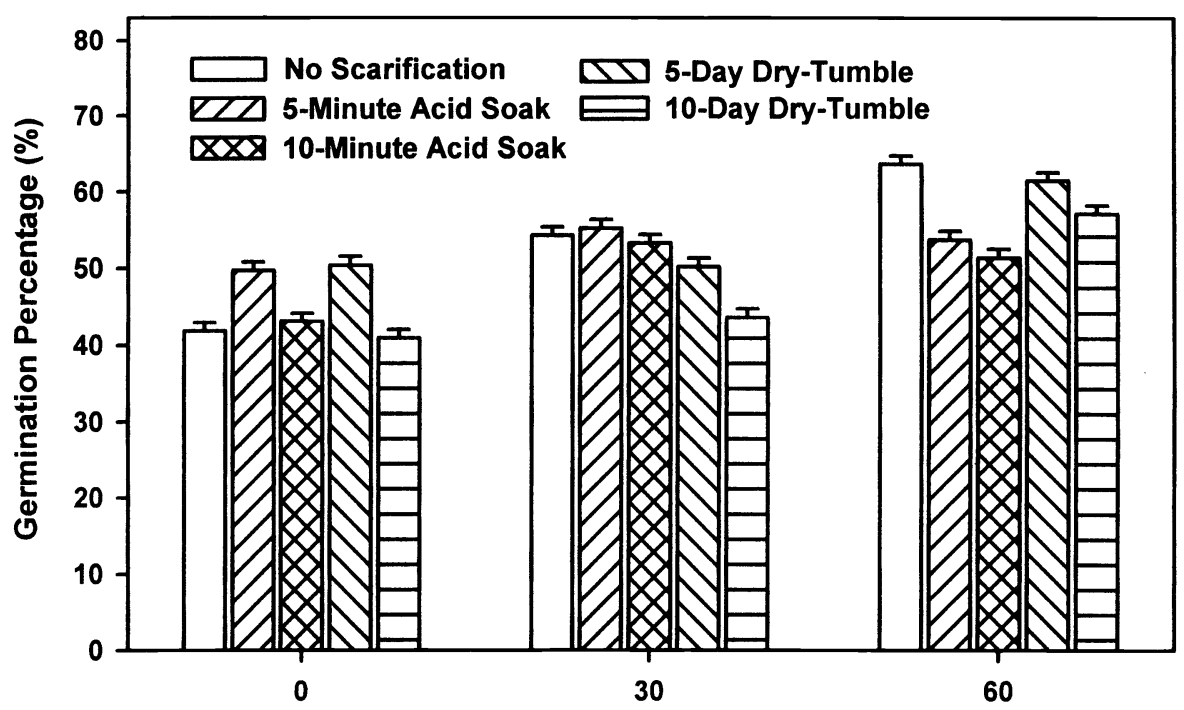

Fig. 3. Effect of interaction between stratification and scarification (averaged across seed

source) on mountain mahogany germination for the 5 -source experiment.

only when no stratification was used. The interaction between stratification and scarification also varied among seed sources (Fig. 4). For 5 of 8 seed sources, benefit of scarification was lost when stratification was increased to 60 days. However, for the remaining 3 sources, a 5 -minute acid soak improved germination even when combined with the longest (60 days) stratification treatment.

\section{Discussion}

Overall germinability and response to scarification treatments was highly variable among the New Mexico sources of mountain mahogany studied. Considerable ecotypic differences exist within mountain mahogany species (Young et al. 1978). Ecotypic and environmental differences among populations interact to affect seed dormancy (Baskin and Baskin 1973) and viability, and could account for the variability in reported stratification and scari- fication requirements of mountain mahogany (Hervey 1955, Heit 1970 , Smith 1971, Deitschman et al. 1974, Kitchen and Meyer 1990).

Kitchen and Meyer (1990) found variability in stratification requirements of 9 Utah and Colorado mountain mahogany seed sources to be related to environmental factors such as winter precipitation and the probability of spring drought (but not elevation), in addition to winter temperature. These environmental factors may also account for some of the variability among New Mexico sources, where precipitation varies along latitudinal and elevational gradients. The data in this study suggest a latitudinal gradient in the degree of stratification requirement between northern and southern New Mexico seed sources and an elevational gradient in stratification requirement between upper and lower elevational seed sources at a single location.

Scarification treatments improved germination to a limited extent in this study. As was the case in previous studies, scarification treatments were less effective than stratification in promoting germination (Hervey 1955, Heit 1970, Smith 1971). Scarification in concentrated sulfuric acid was a more effective treatment than drytumble scarification for 4 of 7 sources, but for 2 seed sources, all levels of acid scarification significantly reduced germination. Variability in reported optimal acid-soak duration in mountain mahogany (Hervey 1955, Heit 1970, Dreesen, unpublished data) is likely the result of variability in seed coat thickness among seed lots. Seed coat thickness is a major factor related to both the requirement for and the sensitivity to scarification treatments.

Although acid scarification is often employed to improve seed coat permeability or soften restrictive seed coats, neither of these dormancy mechanisms is documented to occur in mountain mahogany (Heit 1970). However, mountain mahogany seeds contain a water-extractable inhibitor 

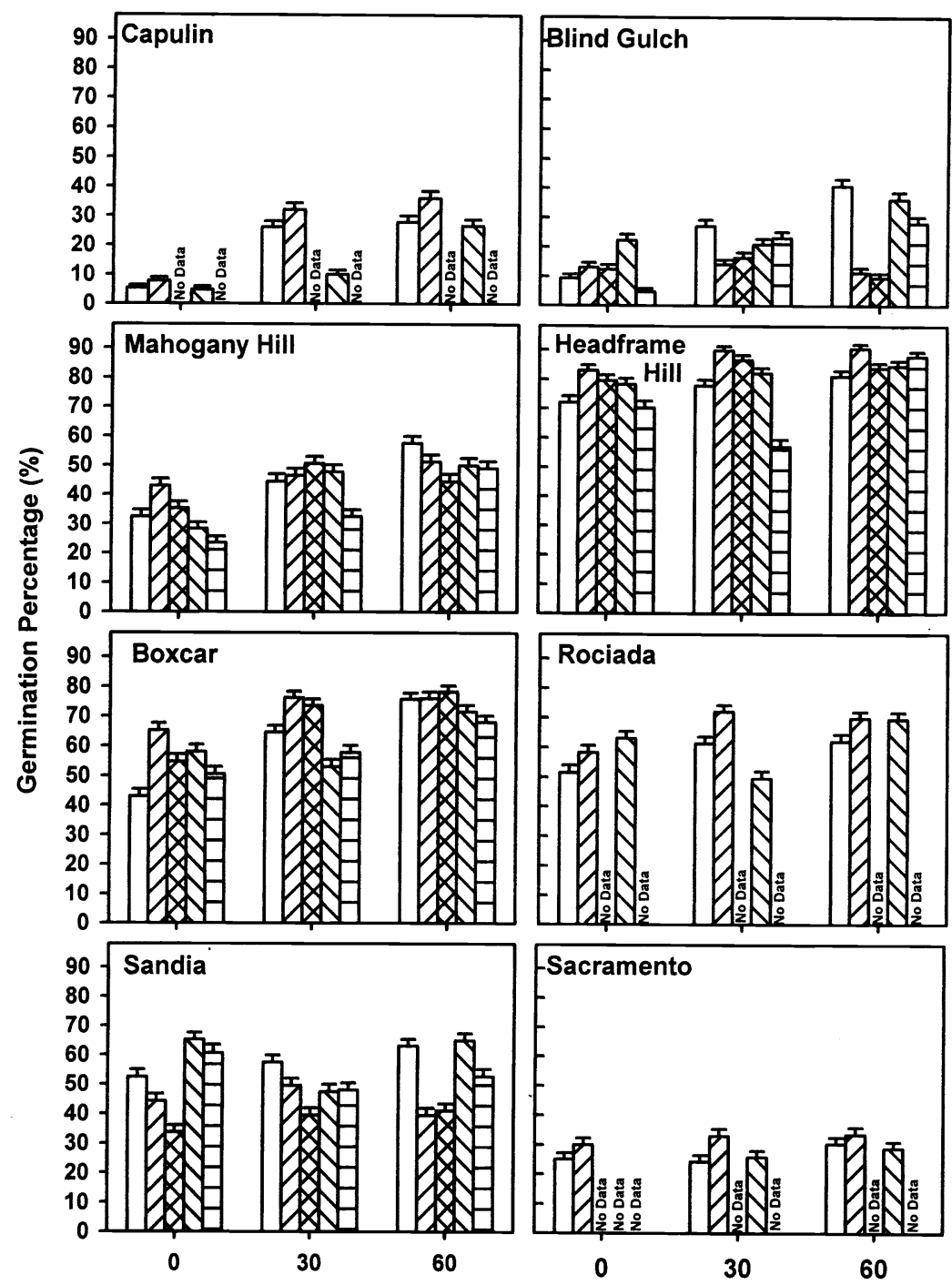

Stratification Duration (days)

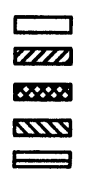

No Scarification

5-Minute Acid Soak 10-Minute Acid Soak

5-Day Dry-Tumble 10-Day Dry-Tumble

Fig. 4. Effect of interaction between seed source, stratification duration, and scarification treatment on mountain mahogany germination.

that may be hydrocyanic acid or a cyanogenic compound (Moore 1963). Acid scarification may chemically alter or remove these germination inhibitors from the seed coat. Dry-tumble scarification, on the other hand, would be expected to be less effective in reducing seed coatinhibitor content. Variable response to acid scarification among seed sources may be explained by variablity in inhibitor content.

There was no elevational or latitudinal trend among sources in response to scarification treatments in this study. Microclimatic, edaphic, and other local biotic and abiotic factors rather than macroclimate may influence seed source response to scarification treatments. This pattern of variability contrasts sharply with variability in stratification requirement, which delineates along macroclimatic gradients.

\section{Literature Cited}

Baskin, C.C. and J.M. Baskin. 1973. Plant population differences in dormancy and germination characteristics of seed: heredity or environment? Amer. Midl. Nat. 90(2):493-498.
Brotherson, J.D. 1992. Mineral nutrient concentrations in the mountain mahogany species Cercocarpus montanus and Cercocarpus intricatus and in their associated soils. J. Plant Nutr. 15(1):49-67.

Deitschman, G.H., K.R. Jorgenson, and A.P. Plummer. 1974. Cercocarpus H.B.K. p. 309-312. In: C.S. Schopmeyer (coord.) Seeds of Woody Plants in the United States. Agr. Handb. No. 450. USDA, U.S. Government Printing Office, Washington, D.C.

Heit, C.E. 1970. Germination characteristics and optimum testing methods for twelve western shrub species. Proc. Assoc. Official Seed Analysts. 60:197-205.

Hervey, D.F. 1955. Factors which influence the reseeding of certain browse species in Colorado. Ph.D. Diss., A\&M College of Texas. College Station, Tex.

Kitchen, S.G. and S.E. Meyer. 1990. Seed dormancy in two species of mountain mahogany (Cercocarpus ledifolius and Cercocarpus montanus). In: K.L. Johnson (ed.) Proc. Fifth Utah Shrub Ecology Workshop. Utah State Univ., Logan, Ut.

Kitchen, S.G., S.E. Meyer, G.R.Wilson, and R. Stevens. 1989. Addition of Cercocarpus montanus - true mountain-mahogany-to the rules. Assoc. Official Seed Analysts Newsletter 63:28-30.

Moore, T.C. 1963. A germination inhibitor in achenes of Cercocarpus montanus. Ecol. 42(2):406-408.

Paschke, M.W. 1997. Actinorhizal plants in rangelands of the western United States. J. Range Manage. 50 (1):62-67.

Piatt, J.R. 1976. Effect of water stress and temperature on germination of true mountain mahogany. J. Range Manage. 29(2):138-140.

Rosner, L.R. 2000. Variability in seed propagation requirements of two co-occurring montane shrub species-Symphoricarpos oreophilus (mountain snowberry) and Ribes cereum (wax currant). Masters Thesis, New Mexico State Univ. Las Cruces, N.M.

SAS Institute Inc. 1989. SAS/STAT Users Guide, Version 6, Fourth Edition, Volume 11. SAS Inst. Inc., Cary, N.C.

Smith, D.R. 1971. Growth Responses of true mountain mahogany on four soil types within the front range of Colorado. Ph.D. Diss., Utah State Univ. Logan, Ut.

Smith, D.R. and L.N. Bass. 1973. Germinability of true mountain mahogany achenes as influenced by soil and other environmental factors. Proc. Assoc. Official Seed Analysts 63:26-134.

Springfield, H.W. 1973. Cliffrose and mountain mahogany seeds retain viability 6 years in cold storage. USDA For. Serv. Res. Note RM-236.

Young, J.A. and R.A. Evans. 1981. Germination of seeds of antelope bitterbrush, desert bitterbrush, and cliff rose. Agricultural Research Results. ARR-W-17. USDA Sci. and Educ. Admin.

Young, J.A., R.A. Evans, and D.L. Neal. 1978. Treatment of curlleaf Cercocarpus seeds to enhance germination. J. Range Manage. 42(3): 614-620. 